\title{
What Causes the Differences in Management Practices between US and UK? An Application of Decomposition Analysis on Firms across Countries
}

\author{
Yi Su${ }^{1,2 *}$, Baoding Liư ${ }^{1}$, Dan Li ${ }^{1}$ \\ ${ }^{1}$ School of Economics and Management, Harbin Engineering University, Harbin, China \\ ${ }^{2}$ School of Management, University of Bradford, Bradford, UK \\ Email: *suyi@hrbeu.edu.cn
}

How to cite this paper: Su, Y., Liu, B.D. and Li, D. (2018) What Causes the Differences in Management Practices between US and UK? An Application of Decomposition Analysis on Firms across Countries. Theoretical Economics Letters, 8, 1684-1700. https://doi.org/10.4236/tel.2018.810109

Received: October 15, 2017

Accepted: December 28, 2017

Published: June 19, 2018

Copyright $\odot 2018$ by authors and Scientific Research Publishing Inc. This work is licensed under the Creative Commons Attribution International License (CC BY 4.0). http://creativecommons.org/licenses/by/4.0/

\section{Open Access}

\begin{abstract}
The aim of this study is to examine what makes the differences of management practices between the United States and the United Kingdom using decomposition analysis. First, this study analyzes the determinants of management practices, and does the empirical research. Determinants of management practices are concluding product market competition, ownership, firm age, human resources (education, working hours, and payment). Essentially we argue that the differences (if any) between US and UK's management practices can be expanded by product market competition and education. The results demonstrate that education (managers' degree and employees' degree) is positively correlated with management practice gap, but the impact of competition on management practices gap is negative. In particular, employees' degree variables explained approximately $70 \%$ of the management gap.
\end{abstract}

\section{Keywords}

Management Practices, Gap, Decomposition Analysis, US, UK

\section{Introduction}

As creating value is the most primary pursuit of a firm [1], economists pay more attention on the relationship between firms' resources and value creation [2] [3]. On the one hand, resource-based view (RBV) suggests that possessing rare and inimitable resources can develop the competitive advantage [4], and provides the basis for sustainable value creation [5]. The effectiveness of resources (skilled 
employees') will be limited, however, if they are not motivated to perform their jobs [6]. On the other hand, contingency theory (the alternative perspective) suggests that all management practices are contingent on the firm's environment. The key concept in a contingent proposition is fit [7], and the fit is between environmental contingencies and internal configurations may lead to greater understanding of how resources can be managed to optimize value creation, because firms do not operate in a vacuum [3] [8]. Contingency theory has been used in the area of business strategy [9] [10] [11], quality management [12], organizational change [13]. Some new theories, such as structural contingency theory [7], which examines whether context-structure relationship affected performance, and a contingent resource-based view [9] [14] [15], has been developed. In this view, every firm is adopting its own best practices given the circumstance in which it finds itself, but contingency is not the whole story [16].

People have long puzzled over the astounding phenomenon that even possessing the same resources (physical assets, technologies, and human skills) and facing similar environmental (country and industry), values the firm created vary substantially [9] [16]. This means in the order to guarantee the development of competitive advantage and the creation of value [11] [17], firms need to adopt new machinery or technological innovations [16] [18], and find a right way to manage (accumulate, combine, and exploit) the resources [19] [20]. Despite the critical role that the management practices plays, few studies have carefully examined its implications [21]. The main reason that scholars have tend to shy away from this is that it is hard to explain how to measure management across countries [22]. Bloom and Van Reenen (2007, 2010) have developed a new survey methodology, which is an interview-based evaluation tool, to measure management practices in three areas (monitoring, targets, and incentives).

The management practices play a critical role, especially the management practice across countries. More and more enterprises are increasingly placing importance on management practices in an attempt to improve their competitive position. There is little empirical evidence regarding the differences of management practices between countries. One of the main contributions of this study is the decomposition of management practices, and focuses on what makes the differences of management between US and UK. The impact of competition on management practices is inconclusive, partly because of the method's problems but mainly because of the data we used. Beyond that, comparative static and even dynamic studies of management practice are required.

The remainder of the paper is organized as follows. In Section 2, the determinants of management practices are discussed. Section 3 contains linear regression equation model, decomposition analysis model, and data issues. In Section 4 , results of decomposition analysis are presented. Finally, Section 5 draws the main conclusions. 


\section{Determinations of Management Practices}

\subsection{Product Market Competition}

Management practices are likely to lead to improved firms' performance, but this is subject to one qualification that relates to the degree of intensity of market competition [23], which is a key situational factor in the total number of factors that comprise the firm's environment [24]. The rapid development of globalization of product markets [25], which means the competitive threats, challenges, stess [26] and higher risk [27], has caused manufacturing firms to search for an appropriate management technique to enhance the survive rate (Mia \& Clarke, 1999) [28]. "Monopoly... is a great enemy to good management" [29]. That means the degree of product market competition faced by a firm likely influences its management practices [6] [30] [31]. Strong product market competition appears to boost average management practices through a combination of eliminating the tail of badly managed firms and pushing incumbents to improve their practices. Competition encourages managers' to avoid wasteful investments [32], and has a significant effect on its inclination to management innovate [33]. Progressive management practices and advanced organizational methods are more prevalent in countries and industries where product market competition is strong [16] [34] [35]. Information asymmetry between managers' and the market is lower and stock-price informativeness is higher in more competitive markets [6] [36]. In competitive markets it becomes easier to benchmark the performance of the managers' against the best practice among the competing firms [30], so reductions in slack resources due to competition constrain managers" discretionary behavior [37]. Greater competition also leads to a higher threat of liquidation, which leads managers' to increase equity and reduce debt [38]. In the case of regulated markets with few, if any, competitors, the owners have a limited ability to monitor their managers' by benchmarking the performance and management practices of their company against other competing companies [30]. Further, the greater discretion in decision-making managers' receive with greater competition gives them greater latitude to engage in such opportunistic actions as their actions are less observable or understandable due to their complex nature. Thus, the higher the intensity of market competition, the better a management must be.

\subsection{Ownership}

There are two theoretical perspectives, named agency theory and stewardship theory, provide a broader framework to explore the ownership and management issues [39]. Agency theory begin with the premise that managers' and owners (shareholders) may have divergent interests [40]. In addition, Stewardship theory, which has been presented as a useful framework to examine the ownership and management [41] [42], suggests that the interests of owner and manager can be coincide. In this paper, the firms are divided into institution ownership and non-institution ownership. On one hand, the managerial view, originated 
from the agency theory, argues that firms under institution ownership struggle to exercise control on their managers', as an individual owner does not have strong incentives to monitor managers' [43] [44] [45]. Because of the inadequate information about managerial actions, the institution owned firms are typically managed badly. On the other hand, non-institution ownership firms, such as family owned firms, are typically much better managed [46] [47].

\subsection{Firm Age}

Firm age, how long a firm has operated, can let managers' have a sense of belonging and trust. Firm age is calculated as survey year minus the founding year [48]. It is used to capture any founding values [49] and maturation effects [6]. There is positive impact of firm age on management practice, consistent with the hypothesis of a progressive improvement of the managerial factor over time. The role played by firm age in shaping the behavior of family managers' over time, and plays a crucial role when a learning process is at work [50]. However, a progressive decline in managerial performance over time, supported by negative-albeit not significant-coefficients in older age cohorts.

\subsection{Human Resources (Managers' and Employees')}

The poor performance of management practices may be attributed to negligence in human resources [23] [51] [52], such as training and staffing selectivity [23] [53]. Selectivity in staffing, such as educated managers' hired, is positively related to management practices performance. New management practices are often complex and hard to introduce without the assistance of managers' or consultants with prior experience of these innovations [54]. Firms that more intensively use human capital, as measured by more educated workers (managers' and employees'), tend to have much better management practices. Education is strongly correlated with high management scores, whether one looks at the education level of managers' or of workers. We cannot infer a causal relationship from this association, of course, but it is plausible that managers' with an MBA or college education are more likely to be aware of the benefits of modern management practices like lean manufacturing. More surprisingly perhaps, is that worker-level education is also positively associated with management scores, suggesting that implementing many of these practices may be easier when the workforce is more knowledgeable. Our belief is that more basic business education, for example around capital budgeting, data analysis, and standard human resources practices, could help improve management in many nations [16].

Working hours and payment are also likely to influence management practices. Firstly, additional work hours may cause high work intensity or work pressure, which may result in fatigue [55]. The setting of working hours by owners tends to raise work demands above the optimal choice level for managers' [56]. Secondly, payment is also a core management practices influence factor. The public sector (such as state ownership firms) is locked into a pay structure that 
limits the ability to link management salaries to performance [30], named performance-related pay [57], and always provides stronger job security. As for this, managers' may put less effort into their jobs and hence have less incentive to perform well. Managers' can expect their efforts to be fairly rewarded [58] [59], so firms can implement merit pay or incentive compensation systems that provide rewards to managers' for meeting specific goals. If not, managers' may engage in short-run cost-augmenting activities designed to enhance their non-salary income, or to provide other forms of on-the-job consumption [60] [61]. This occurs because as management's right to residual income decreases they appropriate income from other corporate sources in the form of assorted perks [40].

\section{Model and Data}

\subsection{Linear Regression Model}

The first step in specifying the linear regression equation model is to determine whether the product market competition, ownership, firm age, human resources (managers' and employees') are the determinations of management practices.

\subsection{Decomposition Analysis Model}

In order to examine the determinants of the management practices' gap between various kinds of firms in UK and US, we used the method of Oaxacae-Blinder decomposition [62] [63], by using Stata version 12.1. Since the management practices' gap reflects the differences in the group means of the outcome, it lends itself to the decomposition analysis of the group means of determinants. This methodology decomposes the observed group difference in outcome into two main components: the disparity associated with the differences in determinants and the disparity associated with the differential response by groups to those determinants [51]. It is often used to study labor-market outcomes by two groups (sex, race, and so on), and divides the wage differential between two groups into "explained" and "unexplained" part. Education and work experience are always used as the determinants in the "explained" part. The "unexplained" part also subsumes the effects of group differences in unobserved predictors [64] [65]. This method can also be useful in other fields, such as health inequalities [66], public health [67] [68], cross-country differences in obesity [69] [70], body mass [51], non-farm income [71]. In general, the technique can be employed to study group differences in any (continuous and unbounded) outcome variable.

The Oaxacae-Blinder decomposition was implemented in the following form:

$$
\bar{M}_{U S}-\bar{M}_{U K}=\bar{X}_{U S}^{\prime} \hat{\beta}_{U S}-\bar{X}_{U K}^{\prime} \hat{\beta}_{U K}=\left(\bar{X}_{U S}^{\prime}-\bar{X}_{U K}^{\prime}\right) \hat{\beta}+\bar{X}^{\prime}\left(\hat{\beta}_{U S}-\hat{\beta}_{U K}\right)
$$

where indices US and UK indicate US firms and UK firms, $M_{U S}$ and $M_{U K}$ are the mean management practices for the respective firms, $\mathrm{X}$ is the vector containing the means of the covariates, and $\hat{\beta}$ is the vector containing a weighted average of the estimated coefficients for US firms, $\hat{\beta}_{U S}$, and for UK firms, $\hat{\beta}_{U K}$. 
The Oaxacae Blinder decomposition decomposes the difference in management practices between two groups into those due to the group differences in means of explanatory variables and those due to the group differences in the estimated coefficients.

$$
\bar{M}_{U S}-\bar{M}_{U K}=\left(\bar{X}_{U S}^{\prime}-\bar{X}_{U K}^{\prime}\right) \hat{\beta}^{*}+\bar{X}_{U S}^{\prime}\left(\hat{\beta}_{U S}-\hat{\beta}_{U K}\right)+\left(\bar{X}_{U S}^{\prime}-\bar{X}_{U K}^{\prime}\right)\left(\hat{\beta}_{U S}-\hat{\beta}_{U K}\right)
$$

This is a "threefold" decomposition. The first component, $\left(\bar{X}_{U S}^{\prime}-\bar{X}_{U K}^{\prime}\right) \hat{\beta}^{*}$, amounts to the part of the differential that is due to group differences in the predictors, that is called "endowment effect". The second component, $\bar{X}_{U S}^{\prime}\left(\hat{\beta}_{U S}-\hat{\beta}_{U K}\right)$, measures the contribution of differences in the coefficients. The last component, $\left(\bar{X}_{U S}^{\prime}-\bar{X}_{U K}^{\prime}\right)\left(\hat{\beta}_{U S}-\hat{\beta}_{U K}\right)$, is an interaction term accounting for the fact that differences in endowment and coefficients exist simultaneously between two groups.

Not only is the total decomposition of the outcome differential into an explained part of interest, but also the detailed contributions of the single predictors or sets of predictors are subject to investigation. In the order to evaluate how much of the management practices' gap is due to differences in product market competition, and how much is due to differences in education (managers' degree and employees' degree), we followed the method proposed by Yun (2005)which used to do the detailed decomposition.

Our model specification began with a base model of product market managers' degree (Model 1), and then sequentially added employees' degree (Model 2), and product market competition (Model 3), to assess to what extent the management practices gaps can be explained by these factors.

\subsection{Data}

This study adopted the following indicators as input variables: the product market competition $\left(X_{1}\right)$, ownership $\left(X_{2}\right)$, firm age $\left(X_{3}\right)$, managers' degree $\left(X_{4}\right)$, employees' degree $\left(X_{5}\right)$, managers' working hours $\left(X_{6}\right)$, and managers' payment $\left(X_{7}\right)$. The product market competition $\left(X_{1}\right)$ is measured with two commonly utilized indicators. The first indicator is subjective: managers' told how many competitors they faced $\left(X_{\mathrm{la}}\right)$. The second indicator is more objective in that it measured by imports as a share of domestic production $\left(X_{1 \mathrm{~b}}\right)$. The ownership $\left(X_{2}\right)$ can be divided up ultimate ownership: including institution ownership $\left(X_{2}=0\right)$ and non-institution ownership $\left(X_{2}=1\right)$. The firm age $\left(X_{3}\right)$ calculated as surver year minus the founding year. The managers' degree $\left(X_{4}\right)$ and employees' degree $\left(X_{5}\right)$ is measured by the percentage of managers', who are with an MBA degree, and employees', who are with college education, respectively. The managers' working hours $\left(X_{6}\right)$ are the average hours per week of all managers'. The managers' payment $\left(X_{7}\right)$ is log of CEO salary as reported in company accounts.

The output variables adopted in this study are as follows: management $(Y)$, it is the average management score across questions and interviews. The final sample size comprises 441 American and British companies.

Summary statistics and sample sizes are presented in Table 1. 
Table 1. Overview of the variables and summary statistics.

\begin{tabular}{|c|c|c|c|c|c|c|c|c|c|}
\hline \multirow{3}{*}{$\begin{array}{c}\begin{array}{c}\text { Number of } \\
\text { observations: } 441\end{array} \\
\text { US Firms }\end{array}$} & \multirow{3}{*}{$\begin{array}{c}\text { Outcome measure } \\
\text { Management } \\
\text { Practices }\end{array}$} & \multicolumn{8}{|c|}{ Income measure } \\
\hline & & \multicolumn{2}{|c|}{ competition } & \multirow[b]{2}{*}{ ownership } & \multirow[b]{2}{*}{ Firm age } & \multicolumn{4}{|c|}{ Human Resources } \\
\hline & & $\mathrm{X}_{\mathrm{la}}$ & $\mathrm{X}_{\mathrm{lb}}$ & & & $\begin{array}{c}\text { managers' } \\
\text { degree }\end{array}$ & $\begin{array}{c}\text { Employees' } \\
\text { degree }\end{array}$ & hours & Payment \\
\hline Minimum & 1.61 & 0 & -3.90 & 0 & 1.39 & 0 & 0.69 & 30 & 4.55 \\
\hline Maximum & 4.83 & 3 & 0.70 & 1 & 5.34 & 40 & 4.55 & 80 & 8.04 \\
\hline Mean & 3.32 & 2.47 & -1.70 & - & 3.57 & 1.90 & 3.15 & 48.03 & 6.26 \\
\hline Std. Deviation & 0.72 & 0.69 & 0.73 & - & 0.80 & 4.43 & 0.81 & 5.70 & 0.67 \\
\hline UK Firms & $\begin{array}{c}\text { Management } \\
\text { Practices }\end{array}$ & $\mathrm{X}_{\mathrm{la}}$ & $\mathrm{X}_{1 \mathrm{~b}}$ & ownership & Firm age & $\begin{array}{c}\text { managers' } \\
\text { degree }\end{array}$ & $\begin{array}{c}\text { Employees' } \\
\text { degree }\end{array}$ & hours & Payment \\
\hline Minimum & 1.06 & 0 & -2.72 & 0 & 1.10 & 0 & 0.69 & 35 & - \\
\hline Maximum & 4.86 & 3 & 0.25 & 1 & 5.50 & 15 & 4.17 & 60 & - \\
\hline Mean & 3.04 & 2.25 & -1.02 & - & 3.31 & 0.73 & 2.32 & 44.20 & - \\
\hline Std. Deviation & 0.81 & 0.97 & 0.59 & - & 1.04 & 2.02 & 0.81 & 6.40 & - \\
\hline
\end{tabular}

\section{Results}

\subsection{Linear Regression Equation Model}

Regression analysis is used to investigate determinations of management practices. Regression results in Table 2 show that all independent variables have positive effects on management practices except ownership, which has negative effect although not significant. The coefficient $(-0.0447)$ suggests that institution ownership firms are better managed then non-institution ownership ones, but not significant. This is because that non-institution ownership including family ownership with an external chief executive officer, family ownership with a family chief executive officer, and other ownership. The inherited family-owned firms who appoint a family member as chief executive officer are very badly managed on average. There are two owner-manager conflicts, first owner-manager conflict is that shareholders wish to maximize profits while managers' may prefer various self-interested, nonprofit-maximizing strategies and that concentrated ownership obviates the problems created by these divergent interests [72]. This can be mitigated due to the large shareholder's greater incentives to monitor the manager [60] [73]. The second type of conflict is that the large shareholder may use its controlling position in the firm to extract private benefits at the expense of the small shareholders, and its incentives for monitoring the manager are smal [74]. Because family management reduces and can even eliminate first owner-manager conflict, agency theory would predict a positive effect on the value of family management. Yet, this effect may be offset by the costs of family management if hired professionals are better managers' than family founders or their heirs [46] [47]. It may be preferable for owners of family ownership firms to recruit nonfamily professional managers' (Westhead \& 
Table 2. Determinations of Management Practices.

\begin{tabular}{|c|c|c|}
\hline & & Dependent variable \\
\hline & & Management Practices \\
\hline \multirow[t]{2}{*}{ Competition } & $X_{1 \mathrm{a}}$ & $\begin{array}{c}0.0463 \\
(0.0848)\end{array}$ \\
\hline & $X_{1 \mathrm{~b}}$ & $\begin{array}{l}0.2912^{* * *} \\
(0.0656)\end{array}$ \\
\hline ownership & $X_{2}$ & $\begin{array}{l}-0.0447 \\
(0.0971)\end{array}$ \\
\hline Firm age & $X_{3}$ & $\begin{array}{c}0.0034 \\
(0.0613)\end{array}$ \\
\hline Managers' degree & $X_{4}$ & $\begin{array}{l}0.0223^{* *} \\
(0.0099)\end{array}$ \\
\hline Employees' degree & $X_{5}$ & $\begin{array}{l}0.1549 * * \\
(0.0640)\end{array}$ \\
\hline Managers' working hours & $X_{6}$ & $\begin{array}{c}0.0259^{* * *} \\
(0.0080)\end{array}$ \\
\hline Managers' Payment & $X_{7}$ & $\begin{array}{c}0.0622 \\
(0.0731)\end{array}$ \\
\hline constant & & $\begin{array}{l}1.5596^{* *} \\
(0.6894)\end{array}$ \\
\hline $\mathrm{F}$ & & $6.93^{\star * *}$ \\
\hline R-squared & & 0.2206 \\
\hline Adj R-squared & & 0.1887 \\
\hline VIF & & 1.14 \\
\hline Omitted Variables Test & & $\begin{array}{c}0.19 \\
(\text { Prob }>\text { F }=0.9012)\end{array}$ \\
\hline Heteroskedasticity test & & $\begin{array}{c}0.58 \\
(\text { Prob }>\text { chi } 2=0.4458)\end{array}$ \\
\hline
\end{tabular}

Note: ${ }^{*},{ }^{* *},{ }^{* *}$ represents significance at the $10 \%, 5 \%$, and $1 \%$ level, respectively.

Howorth, 2006) [75], and "Outside" managers' can provide firms with expert advice, specialist skills, and resources that a family firm does not possess [44].

Part 1 of competition $\left(X_{1 \mathrm{a}}\right)$, firm age $\left(X_{3}\right)$ and managers' payment $\left(X_{7}\right)$ have positive effects on management practices, but they are all insignificant. The managers' salaries of are consistent with the management practices. In more recent years, firms have made more flexibility managers' reward systems, which is linking wages and bonuses to enterprise profitability [76] [77], in the order to get well management practices. Part 2 of competition $\left(X_{1 \mathrm{~b}}\right)$ and managers' working hours $\left(X_{6}\right)$ are both positively correlated with management practices and statistically significant at the $1 \%$ level. $1 \%$ increase in competition $\left(X_{1 \mathrm{~b}}\right)$ and managers' working hours $\left(X_{6}\right)$ brings up management practices scores by 0.2912 and 0.0259 percentage points, respectively. Exporting can be a good way to enhance the firms' competition and the management practices. Exporting is considerably more complicated than domestic selling [78]. Exporting can make a manager express better management practices by many ways, such as gathering foreign market information [79]; learning about export tasks such as documentation and export financing [79]; hiring and training additional staff; foreign 
market visits [80]; initiating and making appropriate decisions [80]; attempting to react quickly to unexpected opportunities and change [81]. Firms that export overseas are better-managed than domestic non-exporters [82] [83].

Managers' degree $\left(X_{4}\right)$ and employees' degree $\left(X_{5}\right)$ have positive effects on management practices, statistically significant at the $5 \%$ level. What surprising is that the coefficients $\left(0.1549^{* *}\right.$ and $\left.0.0223^{* *}\right)$ suggests that employees' degree $\left(X_{5}\right)$ plays a more important role in well management practice then managers' degree $\left(X_{4}\right)$.

\section{2. "Threefold" Decomposition}

Management practices vary substantially across countries. In order to examine the determinants of the management practices' gap between various kinds of firms in UK and US, we used the method of Oaxacae-Blinder decomposition [62] [63]. First of all, we need to determine the determinants which may be better-suited to explaining difference between countries. These determinants of the management practices are competition $\left(X_{1 \mathrm{~b}}\right)$, managers' degree $\left(X_{4}\right)$, employees' degree $\left(X_{5}\right)$. Others, like competition $\left(X_{1 \mathrm{a}}\right)$, ownership $\left(X_{2}\right)$, firm age $\left(X_{3}\right)$, managers' working hours $\left(X_{6}\right)$, managers' payment $\left(X_{7}\right)$, are more focused on differences on firm lever. Then we do the threefold decomposition model and detailed decomposition model to analysis the management practices' gap in UK and US.

Oaxaca first estimates two group regression models and then perform the decomposition. As shown in Table 3, all estimated decompositions are statistically insignificant, except the coefficients at the five percent level. The mean management practice score is 3.3526 for US and 3.1750 for UK, yielding a gap of 0.1776 .

The "Coefficients" part reflects the increase of 0.2156, which is even more then the gap(0.1776), indicates that if UK firms applying US firms' coefficient, which means the degree of influence between competition (managers' degree and employees' degree) and management practices, they can manage better than US firms. It accounts all of the total difference (even more), and indicates that it is very important for the UK firms to make competition, managers' degree and employees' degree more helpful, if they want to reduce the gap. The first and third part are "Endowments" and "interaction" which measures the simultaneous effect of differences in endowments and coefficients. In our study, they both does not seem to matter much.

\subsection{Detailed Decomposition}

The respective contributions of competition, managers' degree and employees' degree factors to the "explained" part of the management gaps are show in Table 4.

As shown in Table 4, all estimated coefficients are statistically significant at the ten percent level or better, except total coefficient in model 3 . The results are presented for three models that sequentially included each set of covariates: 
Table 3. Threefold decomposition results.

\begin{tabular}{cc}
\hline & Management practices \\
\hline US Firms & $3.3526^{* * *}$ \\
& $(0.4934)$ \\
UK Firms & $3.1750^{* * *}$ \\
& $(0.0776)$ \\
Difference & $0.1776^{*}$ \\
& $(0.0920)$ \\
Decomposition & \\
Endowments & 0.1269 \\
& $(0.1214)$ \\
Coefficients & $0.2156^{*}$ \\
& $(0.1118)$ \\
Interaction & -0.1648 \\
\end{tabular}

Note: ${ }^{*}{ }^{* *},{ }^{* *}$ represents significance at the $10 \%, 5 \%$, and $1 \%$ level, respectively.

Table 4. Detailed decomposition results.

\begin{tabular}{lcccccccccc}
\hline & \multicolumn{9}{c}{ US-UK firms (Management $=0.1776$ units) } \\
\cline { 2 - 10 } Variables & \multicolumn{3}{c}{ Model1 } & \multicolumn{5}{c}{ Model2 } \\
\cline { 2 - 10 } & Coef & S.E. & Perc & Coef & S.E. & Perc & Coef & S.E. & Perc \\
\hline $\begin{array}{c}\text { managers' } \\
\text { degree } \\
\text { employees' } \\
\text { degree }\end{array}$ & $0.0409^{* * *}$ & 0.0146 & $14.80 \%$ & $0.02674^{*}$ & 0.0143 & $15.06 \%$ & $0.0289^{*}$ & 0.0129 & $16.27 \%$ \\
$\begin{array}{c}\text { competition } \\
\text { Total }\end{array}$ & $0.0409^{* * *}$ & 0.0146 & $14.80 \%$ & $0.1678^{* * *}$ & 0.0455 & $94.51 \%$ & 0.0031 & 0.0613 & - \\
\hline
\end{tabular}

Note: ${ }^{*}{ }^{* *},{ }^{* *}$ represents significance at the $10 \%, 5 \%$, and $1 \%$ level, respectively.

Model 1 was the base model with managers' degree; Model 2 added the employees' degree covariates to Model 1; and, Model 3 was the full model that added the competition factors to Model 2.

The results in Table 4 show that the base model (Model 1) that included the managers' degree only explained roughly $14.80 \%$ of the management gaps between two groups. Once employees' degree variable was included, the contribution of the firm size is up to $15.06 \%$. In particular, employees' degree explained approximately $79.45 \%$ (in model 2) of the management gap but explained substantially less (just $66.22 \%$ in Model 3). Two results stand out. On one hand, employees' degree has the most important impact on the management gap. Education, employees' degree, is a useful way to enhance the staffs' skills and ability, both for the individuals hired and current employees [84] [85]. British firms can adopt selectivity in staffing method to get skilled employees. At the same time, they can improve the quality of current employees' by providing comprehensive training and development activities after selection [53] [86] [87].

On the other hand, competition has negative impact $\left(-0.1434^{* * *}\right)$ on the gaps 
explanation. In general, competition imposes on the organization a seemingly conflicting set of demand, and represents turbulence, stress, risk and uncertainty [26]. The United States, which generally has very competitive product markets by international standards, does not have as much of a tail of badly-managed firms as some other countries [16]. US companies have been urged to adopt a variety of performance-enhancing to improve their competitiveness in the global marketplace [6]. However, in this paper he mean of UK competition and US competition are 0.4201 and 0.2354 , respectively. This means UK businesses need to face a more competitor environment than US. That is the reason why there exist negative impacts on the gaps explanation.

\section{Summary and Conclusion}

This study presents an analysis of determinations of management practices, and focuses on what makes the differences of management between US and UK. One of the main contributions of this study is the decomposition of the management discrimination. In addition, the analysis was conducted utilizing world management survey's data, which allows us to measure management discrimination. The management practices gap between US and UK is decomposed into three parts, which are competition, managers' degree and employees' degree. Managers' degree and employees' degree are positively correlated with management practice. In particular, employees' degree variables explained approximately $70 \%$ of the management gap. The impact of competition on management practices is inconclusive, partly because of the method's problems but mainly because of the data we used. Beyond that, comparative static and even dynamic studies of management practice are required. As an exploratory study in an area yet to be fully developed, this paper highlights determinates of management practices for international scholars, and leads the way for further theoretical and empirical studies in the field.

\section{Funding}

This research has been partially supported by the National Natural Science Foundation of China (71403066; 71774036; 71601087); Natural Science Foundation of Heilongjiang Province (QC2018088); Social Science Foundation of Heilongjiang Province (17GLH21); the Special Foundation of Central Universities Basic Research Fee (HEUCFW170907, HEUCF170903, HEUCF180905).

\section{Conflict of Interest}

The authors declare that they have no conflict of interest.

\section{References}

[1] Conner, K.R. (1991) A Historical Comparison of Resource-Based Theory and Five schools of Thought within Industrial Organization Economics: Do We Have a New Theory of the Firm? Journal of Management, 17, 121-154.

https://doi.org/10.1177/014920639101700109 
[2] Lippman, S.A. and Rumelt, R.P. (2003) A Bargaining Perspective on Resource Advantage. Strategic Management Journal, 24, 1069-1086. https://doi.org/10.1002/smj.345

[3] Sirmon, D.G., Hitt, M.A. and Ireland, R.D. (2007) Managing Firm Resources in Dynamic Environments to Create Value: Looking inside the Black Box. Academy of Management Review, 32, 273-292. https://doi.org/10.5465/amr.2007.23466005

[4] Ireland, R.D., Hitt, M.A. and Sirmon, D.G. (2003) A Model of Strategic Entrepreneurship: The Construct and Its Dimensions. Journal of Management, 29, 963-989. https://doi.org/10.1016/S0149-2063(03)00086-2

[5] Barney, J. (1991) Firm Resources and Sustained Competitive Advantage. Journal of Management, 17, 99-120. https://doi.org/10.1177/014920639101700108

[6] Delaney, J.T. and Huselid, M.A. (1996) The Impact of Human Resource Management Practices on Perceptions of Organizational Performance. Academy of Management Journal, 39, 949-969.

[7] Drazin, R. and Van de Ven, A.H. (1985) Alternative Forms of Fit in Contingency Theory. Administrative Science Quarterly, 514-539.

https://doi.org/10.2307/2392695

[8] Donaldson, L. (2001) The Contingency Theory of Organizations: Sage. https://doi.org/10.4135/9781452229249

[9] Aragon-Correa, J.A. and Sharma, S. (2003) A Contingent Resource-Based View of Proactive Corporate Environmental Strategy. Academy of Management Review, 28, 71-88. https://doi.org/10.5465/amr.2003.8925233

[10] Hofer, C.W. (1975) Toward a Contingency Theory of Business Strategy. Academy of Management Journal, 18, 784-810. https://doi.org/10.5465/255379

[11] Priem, R.L. and Butler, J.E. (2001) Is the Resource-Based "View" a Useful Perspective for Strategic Management Research? Academy of Management Review, 26, $22-40$.

[12] Das, A., Handfield, R.B., Calantone, R.J. and Ghosh, S. (2000) A Contingent View of Quality Management-The Impact of International Competition on Quality. Decision Sciences, 31, 649-690. https://doi.org/10.1111/j.1540-5915.2000.tb00938.x

[13] Battilana, J. and Casciaro, T. (2012) Change Agents, Networks, and Institutions: A Contingency Theory of Organizational Change. Academy of Management Journal, 55, 381-398. https://doi.org/10.5465/amj.2009.0891

[14] Brush, T.H. and Artz, K.W. (1999) Toward a Contingent Resource-Based Theory: The Impact of Information Asymmetry on the Value of Capabilities in Veterinary Medicine. Strategic Management Journal, 20, 223-250. https://doi.org/10.1002/(SICI)1097-0266(199903)20:3<223::AID-SMJ14>3.0.CO;2$\underline{\mathrm{M}}$

[15] Zajac, E.J., Kraatz, M.S. and Bresser, R.K.F. (2000) Modeling the Dynamics of Strategic Fit: A Normative Approach to Strategic Change. Strategic Management Journal, 21, 429-453.

[16] Bloom, N., Sadun, R. and Van Reenen, J. (2010) Does Product Market Competition Lead Firms to Decentralize? The American Economic Review, 100, 434-438.

[17] Barney, J.B. and Arikan, A.M. (2001) The Resource-Based View: Origins and Implications. In: Hitt, M.A., Freeman, R.E. and Harrison, J.S., Eds., The Blackwell Handbook of Strategic Management, Wiley-Blackwell, Hoboken, 124-188.

[18] Abramovitz, M. (1956) Resource and Output Trends in the United States since 1870 Resource and Output Trends in the United States since 1870. NBER, 1-23. 
[19] Grant, R.M. (1991) The Resource-Based Theory of Competitive Advantage: Implications for Strategy Formulation. In: Zack, M., Ed., Knowledge and Strategy, 3-23. https://doi.org/10.2307/41166664

[20] Sirmon, D.G. and Hitt, M.A. (2003) Managing Resources: Linking Unique Resources, Management, and Wealth Creation in Family Firms. Entrepreneurship Theory and Practice, 27, 339-358. https://doi.org/10.1111/1540-8520.t01-1-00013

[21] Saha, S.K. (1993) Managing Human Resources: China vs. the West. Canadian Journal of Administrative Sciences, 10, 167-177. https://doi.org/10.1111/j.1936-4490.1993.tb00025.x

[22] Bloom, N. and Van Reenen, J. (2010) Why Do Management Practices Differ across Firms and Countries? The Journal of Economic Perspectives, 24, 203-224.

[23] Chong, V.K. and Rundus, M.J. (2004) Total Quality Management, Market Competition and Organizational Performance. The British Accounting Review, 36, 155-172. https://doi.org/10.1016/j.bar.2003.10.006

[24] Harbison, F.H. and Myers, C.A. (1959) Management in the Industrial World: An International Analysis. McGraw-Hill, New York.

[25] Simonetti, J.L. and Boseman, F.G. (1975) The Impact of Market Competition on Organization Structure and Effectiveness: A Cross-Cultural Study. Academy of Management Journal, 18, 631-638.

[26] Khandwalla, P.N. (1973) Effect of Competition on the Structure of Top Management Control. Academy of Management Journal, 16, 285-295.

[27] Su, Y. and An, X. (2018) Application of Threshold Regression Analysis to Study the Impact of Regional Technological Innovation Level on Sustainable Development. Renewable and Sustainable Energy Reviews, 89, 27-32. https://doi.org/10.1016/j.rser.2018.03.005

[28] Mia, L. and Clarke, B. (1999) Market Competition, Management Accounting Systems and Business Unit Performance. Management Accounting Research, 10, 137-158. https://doi.org/10.1006/mare.1998.0097

[29] Adam, S. (1776) An Inquiry into the Nature and Causes of the Wealth of Nations. Edwin Cannan's Annotated Edition.

[30] Goldeng, E., Grünfeld, L.A. and Benito, G.R.G. (2008) The Performance Differential between Private and State Owned Enterprises: The Roles of Ownership, Management and Market Structure. Journal of Management Studies, 45, 1244-1273. https://doi.org/10.1111/j.1467-6486.2008.00790.x

[31] Shetty, Y.K. (1971) Ownership, Size, Technology, and Management Development: A Comparative Analysis. Academy of Management Journal, 14, 439-449.

[32] Griffiths, R. (2001) Product Market Competition, Efficiency and Agency Costs: An Empirical Analysis.

[33] Hecker, A. and Ganter, A. (2013) The Influence of Product Market Competition on Technological and Management Innovation: Firm-Level Evidence from a Large-Scale Survey. European Management Review, 10, 17-33. https://doi.org/10.1111/emre.12005

[34] Bloom, N. and Van Reenen, J. (2006) Measuring and Explaining Management Practices across Firms and Countries. National Bureau of Economic Research.

[35] Hashem, G. and Tann, J. (2007) The Adoption of ISO 9000 Standards within the Egyptian Context: A Diffusion of Innovation Approach. Total Quality Management, 18, 631-652. https://doi.org/10.1080/14783360701349435

[36] Marciukaityte, D. and Park, J.C. (2009) Market Competition and Earnings Man- 
agement. Drexel University and Auburn University, College of Business, Philadelphia. https://doi.org/10.2139/ssrn.1361905

[37] Hart, O.D. (1983) The Market Mechanism as an Incentive Scheme. The Bell Journal of Economics, 14, 366-382. https://doi.org/10.2307/3003639

[38] Karuna, C., Subramanyam, K.R. and Tian, F. (2012) Industry Product Market Competition and Earnings Management. Paper Presented at the American Accounting Association Financial Accounting and Reporting Section Mid-Year Conference.

[39] Klein, S.B., Pieper, T.M. and Jaskiewicz, P. (2005) Antecedents for Agency and Stewardship Orientation in Corporate Governance-The Role of Culture. Paper Presented at the Research Proposal for Family Enterprise Research Conference, European Family Business Centre (European Business School).

[40] Gedajlovic, E.R. and Shapiro, D.M. (1998) Management and Ownership Effects: Evidence from Five Countries. Strategic Management Journal, 19, 533-553. https://doi.org/10.1002/(SICI)1097-0266(199806)19:6<533::AID-SMJ957>3.0.CO;2$\#$

[41] Lee, P.M. and O'neill, H.M. (2003) Ownership Structures and R and D Investments of US and Japanese Firms: Agency and Stewardship Perspectives. Academy of Management Journal, 46, 212-225.

[42] Sharma, P. (2002) Stakeholder Mapping Technique: Toward the Development of a Family Firm Typology. 62nd Meeting of the Academy of Management, Denver, August 2002, 1-24.

[43] Assaf, A. and Cvelbar, K.L. (2011) Privatization, Market Competition, International Attractiveness, Management Tenure and Hotel Performance: Evidence from Slovenia. International Journal of Hospitality Management, 30, 391-397. https://doi.org/10.1016/j.ijhm.2010.03.012

[44] Gupta, N. (2005) Partial Privatization and Firm Performance. The Journal of Finance, 60, 987-1015. https://doi.org/10.1111/j.1540-6261.2005.00753.x

[45] Laffont, J.-J. (1993) A Theory of Incentives in Procurement and Regulation. MIT Press, Cambridge.

[46] Burkart, M., Panunzi, F. and Shleifer, A. (2003) Family Firms. The Journal of Finance, 58, 2167-2202. https://doi.org/10.1111/1540-6261.00601

[47] Caselli, F. and Gennaioli, N. (2013) Dynastic Management. Economic Inquiry, 51, 971-996. https://doi.org/10.1111/j.1465-7295.2012.00467.x

[48] Li, J., Chu, C.W.L., Lam, K.C.K. and Liao, S. (2011) Age Diversity and Firm Performance in an Emerging Economy: Implications for Cross-Cultural Human Resource Management. Human Resource Management, 50, 247-270. https://doi.org/10.1002/hrm.20416

[49] Stinchcombe, A.L. (2000) Social Structure and Organizations. Advances in Strategic Management, 17, 229-259. https://doi.org/10.1016/S0742-3322(00)17019-6

[50] Cucculelli, M., Mannarino, L., Pupo, V. and Ricotta, F. (2014) Owner-Management, Firm Age, and Productivity in Italian Family Firms. Journal of Small Business Management, 52, 325-343. https://doi.org/10.1111/jsbm.12103

[51] Powell, L.M., Wada, R., Krauss, R.C. and Wang, Y. (2012) Ethnic Disparities in Adolescent Body Mass Index in the United States: The Role of Parental Socioeconomic Status and Economic Contextual Factors. Social Science and Medicine, 75, 469-476. https://doi.org/10.1016/j.socscimed.2012.03.019

[52] Sterman, J.D., Repenning, N.P. and Kofman, F. (1997) Unanticipated Side Effects of 
Successful Quality Programs: Exploring a Paradox of Organizational Improvement. Management Science, 43, 503-521. https://doi.org/10.1287/mnsc.43.4.503

[53] Knoke, D. and Kalleberg, A.L. (1994) Job Training in US Organizations. American Sociological Review, 59, 537-546. https://doi.org/10.2307/2095930

[54] Acemoglu, D., Aghion, P., Lelarge, C., Van Reenen, J. and Zilibotti, F. (2006) Technology, Information and the Decentralization of the Firm. National Bureau of Economic Research.

[55] White, M., Hill, S., McGovern, P., Mills, C. and Smeaton, D. (2003) "High-Performance" Management Practices, Working Hours and Work-Life Balance. British Journal of Industrial Relations, 41, 175-195. https://doi.org/10.1111/1467-8543.00268

[56] Clarkberg, M. and Moen, P. (2001) Understanding the Time-Squeeze Married Couples' Preferred and Actual Work-Hour Strategies. American Behavioral Scientist, 44, 1115-1136.

[57] Schulze, W.S., Lubatkin, M.H. and Dino, R.N. (2003) Toward a Theory of Agency and Altruism in Family Firms. Journal of Business Venturing, 18, 473-490.

https://doi.org/10.1016/S0883-9026(03)00054-5

[58] Ichniowski, C. (1986) The Effects of Grievance Activity on Productivity. Industrial and Labor Relations Review, 40, 75-89.

https://doi.org/10.1177/001979398604000106

[59] Ichniowski, C., Shaw, K. and Prennushi, G. (1995) The Effects of Human Resource Management Practices on Productivity. National Bureau of Economic Research.

[60] Jensen, M.C. and Meckling, W.H. (1979) Theory of the Firm: Managerial Behavior, Agency Costs, and Ownership Structure. Springer, Berlin.

[61] Williamson, O.E. (1967) The Economics of Discretionary Behavior: Managerial Objectives in a Theory of the Firm. Markham Publishing Company, Chicago.

[62] Blinder, A.S. (1973) Wage Discrimination: Reduced Form and Structural Estimates. Journal of Human Resources, 8, 436-455. https://doi.org/10.2307/144855

[63] Oaxaca, R. (1973) Male-Female Wage Differentials in Urban Labor Markets. International Economic Review, 14, 693-709. https://doi.org/10.2307/2525981

[64] Stanley, T.D. and Jarrell, S.B. (1998) Gender Wage Discrimination Bias? A Meta-Regression Analysis. Journal of Human Resources, 33, 947-973. https://doi.org/10.2307/146404

[65] Weichselbaumer, D. and Winter-Ebmer, R. (2005) A Meta-Analysis of the International Gender Wage Gap. Journal of Economic Surveys, 19, 479-511. https://doi.org/10.1111/j.0950-0804.2005.00256.x

[66] O’Donnell, O.A. and Wagstaff, A. (2008) Analyzing Health Equity Using Household Survey Data: A Guide to Techniques and Their Implementation. World Bank Publications.

[67] Chung, W., Lim, S. and Lee, S. (2010) Factors Influencing Gender Differences in Smoking and Their Separate Contributions: Evidence from South Korea. Social Science and Medicine, 70, 1966-1973. https://doi.org/10.1016/j.socscimed.2010.02.025

[68] Halima, M.A.B. and Rococo, E. (2014) Wage Differences According to Health Status in France. Social Science and Medicine, 120, 260-268. https://doi.org/10.1016/j.socscimed.2014.09.035

[69] Auld, M.C. and Powell, L.M. (2006) The Economics of Obesity: Research and Policy Implications from a Canada: US Comparison. Health Services Restructuring in 
Canada: New Evidence and New Directions, Kingston, 17-18 November 2005, 1-25.

[70] Font, J.C., Fabbri, D. and Gil, J. (2010) Decomposing Cross-Country Differences in Levels of Obesity and Overweight: Does the Social Environment Matter? Social Science and Medicine, 70, 1185-1193.

[71] Hwang, J. and Lee, S. (2015) The Effect of the Rural Tourism Policy on Non-Farm Income in South Korea. Tourism Management, 46, 501-513. https://doi.org/10.1016/j.tourman.2014.07.018

[72] Demsetz, H. and Lehn, K. (1985) The Structure of Corporate Ownership: Causes and Consequences. The Journal of Political Economy, 93, 1155-1177. https://doi.org/10.1086/261354

[73] Berle, A.A. and Means, G.G.C. (1991) The Modern Corporation and Private Property. Transaction Publishers, Piscataway.

[74] Villalonga, B. and Amit, R. (2006) How Do Family Ownership, Control and Management Affect Firm Value? Journal of Financial Economics, 80, 385-417.

[75] Westhead, P. and Howorth, C. (2006) Ownership and Management Issues Associated with Family Firm Performance and Company Objectives. Family Business Review, 19, 301-316. https://doi.org/10.1111/j.1741-6248.2006.00077.x

[76] Warner, M. (1996) Human Resources in the People's Republic of China: The "Three Systems" Reforms. Human Resource Management Journal, 6, 32-43. https://doi.org/10.1111/j.1748-8583.1996.tb00402.x

[77] Zhu, C.J. and Dowling, P.J. (2000) Managing People during Economic Transition: The Development of HR Practices in China. Asia Pacific Journal of Human Resources, 38, 84-106. https://doi.org/10.1177/103841110003800207

[78] Christensen, C.H., Da Rocha, A. and Gertner, R.K. (1987) An Empirical Investigation of the Factors Influencing Exporting Success of Brazilian Firms. Journal of International Business Studies, 18, 61-77. https://doi.org/10.1057/palgrave.jibs.8490412

[79] Aaby, N.-E. and Slater, S.F. (1989) Management Influences on Export Performance: A Review of the Empirical Literature 1978-1988. International Marketing Review, 6, 7-26. https://doi.org/10.1108/EUM0000000001516

[80] Cavusgil, S.T. and Naor, J. (1987) Firm and Management Characteristics as Discriminators of Export Marketing Activity. Journal of Business Research, 15, 221-235. https://doi.org/10.1016/0148-2963(87)90025-7

[81] Deng, J., Menguc, B. and Benson, J. (2003) The Impact of Human Resource Management on Export Performance of Chinese Manufacturing Enterprises. Thunderbird International Business Review, 45, 409-429. https://doi.org/10.1002/tie.10088

[82] Burstein, A. and Monge-Naranjo, A. (2007) Foreign Know-How, Firm Control, and the Income of Developing Countries. National Bureau of Economic Research.

[83] Melitz, M., Helpman, E. and Yeaple, S. (2004) Export versus FDI with Heterogeneous Firms. American Economic Review, 94, 300-316.

[84] Becker, B.E. and Huselid, M.A. (1992) The Incentive Effects of Tournament Compensation Systems. Administrative Science Quarterly, 37, 336-350. https://doi.org/10.2307/2393228

[85] Schmidt, F.L., Hunter, J.E., McKenzie, R.C. and Muldrow, T.W. (1979) Impact of Valid Selection Procedures on Work-Force Productivity. Journal of Applied Psychology, 64, 609-626. https://doi.org/10.1037/0021-9010.64.6.609

[86] Bartel, A.P. (1994) Productivity Gains from the Implementation of employee Training Programs. Industrial Relations: A Journal of Economy and Society, 33, 
411-425. https://doi.org/10.1111/j.1468-232X.1994.tb00349.x

[87] Russell, J.S., Terborg, J.R. and Powers, M.L. (1985) Organizational Performance and Organizational Level Training and Support. Personnel Psychology, 38, 849-863. https://doi.org/10.1111/j.1744-6570.1985.tb00570.x 